\title{
The Holocaust in American Historical Writing
}

\author{
GERD KORMAN
}

DERMIT me, an ordinary historian and teacher, presumptuously 1 poking around in other scholars' domains, to clarify some of my passions and fundamental convictions by using for a moment the works of Vladimir Jabotinsky, Alfred Kazin, Albert Speer, and Moses Herzog.

In 1940, Jabotinsky, leader of militant revisionist Zionism, told the world that Hitler's war against all of Europe's Jews would end in their annihilation if the Allies failed to respond constructively to recent events in Europe. As early as 1943, Kazin, subway rider out of Brooklyn's Brownsville Ghetto, literary historian, and writer put it, the pieces of his world, all together: Shmuel Zygelbojm, Warsaw Ghetto, annihilation of European Jewry, and the silence of the many: "all our silent complicity in the massacre of Jews... [whose] deaths were so peculiarly hopeless... means that men are not ashamed of what they have been in this time, and are therefore not prepared for the further outbreaks of fascism which are so deep in all of us." After the war, Speer, Hitler's genius of industrial organization, claimed to have learned in defeat and the distance of time that he could not absolve himself from crimes of omission and acquiescence even though he had understood then that "will alone" could not halt "the automatism of progress" which may well "depersonalize man further and withdraw more and more of his self-responsibility." In the "final analysis I myself determined the degree of my isolation, the extremity of my evasions, and the extent of my ignorance. . ." For "one who wanted to listen," he wrote years later, Hitler never "concealed his intention to exterminate the Jewish people." Saul Bellow's American Jew was a survivor, shocked and on the verge of tears at "the realization of such election. ... As the dead go their way, you want to call to them but they depart in a black cloud of faces, souls. They flew out in smoke from the extermination chimneys, and leave you in the clear light of historical success-the technical success of the West. Then you know with a crash of the blood that mankind is making it-making it in glory though deafened by the explosions of blood." And so, in Poland, where 
he visited, the stones still smelled of war-time murders. "He thought he scented blood."

At bottom, these thoughts making a place for the disaster of European Jewry are not different from the counterrevolutionary interpretive frameworks suggested by some historians in America conscious of the fascism of the mind, and of the impact of a seemingly self-driven accelerating technology. Within these kinds of frameworks the historian considers himself free to do what he will with the Jew. Usually he does it this way, without explicitly involving the Jewish component. "The Dreyfus affair might have awakened in [Marc] Bloch awareness and concern for a problem which at this time some of the greatest of his contemporaries ... began to investigate and which has remained in the center of the study of the social sciences: the limitation of reason and rationality, the strength of the unconscious, the irrational basis of our structured world." Or this way: "Counterrevolutions should be taken in the broadest sense to mean those movements that arose to oppose, divest, absorb, or check the familiar 'isms' that have molded the progressive conception of history. Obviously, what we have here is the obverse side of concern for lost progressive causes."

I am trying to say something else as well. In Herzog and Speer the destruction of Jews is not consuming; it had consumed Zygelbojm and Jabotinsky. In Herzog and Inside the Third Reich it appears as an explicit subject five to ten times. ${ }^{3}$ Both men lived in mental and physical worlds where the Jew in disaster emerged but occasionally: in Herzog's case barely long enough for expressing a fleeting, seering thought. Like Speer, Herzog had many, many other things on his mind.

Historians make explicit and conscious decisions in deciding the importance of Jews in the subject they explore. So did Speer. Thus he writes that in the summer of 1944, his friend Karl Hanke "advised me never to accept an invitation to inspect a concentration camp in Upper Silesia. Never, under any circumstances. ... I did not query him. I did not query Himmler, I did not query Hitler. I did not speak with personal

1 Vladimir Jabotinsky, The Jewish War Front (London, 1940), passim, but see pp. $9,15,19,22$, for comparison with the Armenian disaster and for passages demanding recognition of the war being waged against the Jewish people; Alfred Kazin, "In Every Voice, in Every Ban," The New Republic, CX (January 10, 1944), 46; Albert Speer, Inside the 'Third Reich (London, 1971), pp. 697-698, 171; Saul Bellow, Herzog (Harmondsworth, 1965), pp. 81, 31-32.

2 Felix Gilbert, "Three Twentieth Century Historians," in John Higham, et al., History (Englewood Cliffs, N.J., 1965), pp. 367-368; Leonard Krieger, "European History in America," ibid., p. 307.

3 Bellow, Herzog, pp. 31-32, 60, 80-81, 297. For Speer it is easy enough to consult his index although the one in my paperback edition is inaccurate. 
friends. I did not investigate-for I did not want to know what was happening there." 4

\section{II}

Within ten years after the public discussion of the destruction of European Jewry began in the United States, the Holocaust became a complex problem of contemporary history. So many dogmatic judgments were being made about the people in the disaster that Clio's most devoted disciples were bound to find it difficult to retain their position of detached fair-mindedness. Yet, where historians working in the United States would place the Holocaust in their writings was not quite clear.

William Shirer, of Berlin Diary fame, in 1943 inadvertently identified many of the cross-currents that would help to determine the historiographical status of the Holocaust. From the beginning of the war civilian slaughters, he wrote, left all Germans "completely cold." "From all reports . . . Hitler is believed to have slaughtered two million Jews. . .." But it was wrong for Americans to confuse "the greatest moral problem of our times." "Our inhumanity." The harsh truth is that all our efforts are dependent on Hitler alone. "And even if the five million Jews are saved, what about the twenty million Poles, the fifty million Russians ...." Even in war these remarks prompted Shirer's editor, the famed Paul Kellogg of the magazine Survey, to respond in an editorial comment against so many sweeping generalizations. Kellogg could "only lean on my faith in Germans I have known abroad no less than here" but "my faith is not without support from fugitives who have cleared the border, from the testimony of refugees, from the glimpses of rebel daring that leak out through the underground. These support," he preached, "the living wisdom from Burke to Madame Chiang Kai-sheck [sic] - that you cannot indict a whole people."

Many others contributed to the swirling currents. The Institute of Jewish Affairs, for example, established in 1940, primarily in response to the Hitler years, and through which Jacob Robinson, its director, made himself known, published a number of important studies under the title Starvation Over Europe (1943) and such other titles as Hitler's Ten Year War on the Jews (1943), The Racial State (1944), and The Jewish Catastrophe (1944). In the pages of the labor Zionist Jewish Frontier and in the scholarly Jewish Social Studies appeared a steady stream of explanation, analyses, and judgments from the powerful and provocative pen of Hannah Arendt.

1 Speer, Inside the Third Reich, pp. 506-507.

5 William L. Shirer, "The Nazi Reign of Terror," Survey Graphic, XXXII (April, 1943), 121-122. Kellogg's editorial comment is on p. 122. 
One of these, from 1944, deserves extended quotation, in part because it turned out to be a prophecy about her relationship to the literature on the Holocaust. Thinking especially of Bernard Lazare, Heinrich Heine, and Franz Kafka, but surely as applicable to herself ("bold spirits who tried to make the emancipation of Jews that which it really should have been-an admission of Jews as Jews to the ranks of humanity. . . .") she wrote:

That the status of the Jews in Europe has been not only that of an oppressed people but also of what Max Weber has called a 'pariah people' is a fact most clearly appreciated by those who had practical experience of just how ambiguous is the freedom which emancipation has ensured, and how treacherous the promise of equality which assimilation has held out. In their own position as social outcasts such men reflect the political status of their entire people. It is, therefore, not surprising that out of their personal experience Jewish poets, writers, and artists should have been able to evolve the concept of the pariah as a human type-a concept of supreme importance for the evaluation of mankind in our day and one which has exerted upon the gentile world an influence in strange contrast to the spiritual and political ineffectiveness which has been the fate of these men among their own brethren. ${ }^{6}$

In 1949, in the very months when a Jewish state was being developed in Palestine, these kinds of positions were advanced from the same plat-

${ }^{6}$ Hannah Arendt, "The Jew as Pariah: A Hidden Tradition," Jewish Social Studies, VI (April, 1944), 100. The Institute of Jewish Affairs was a creation of the American Jewish Congress and of the World Jewish Congress. After World War II, YIVO, established in Vilna in 1925, but moved to New York City in 1939, continued the work of the Institute on the subject of the Holocaust. In 1947, the YIVO Bleter was devoted to the subject, and also published Max Weinreich's Hitler's Professors (New York, 1946). After 1953, YIVO continued to publish works on the Holocaust as, for example, Volumes VIII (1954) and XXI (1969) of the Annual of Jewish Social Science, or with Yad Vashem, as for example, the multi-volume bibliography in English, Yiddish, and Hebrew, Guide to Jewish History Under Nazi Impact (9 vols.; New York, 1960-1966). There were, of course, many other sources contributing to information and interpretations about the Holocaust in those years. One steady stream came from the United States Department of State through formal pronouncements from its officials to audiences of different kinds and through the Department's Bulletin. Another came from Jewish organizations and leaders, especially from various Zionists such as Ben Hecht and Rabbi Abba Silver. In addition to the newspaper reports about the Nuremberg Trial, see Seymour Krieger, Nazi Germany's War Against the Jews (New York, 1947); Eugene Davidson, The Trial of the Germans (New York, 1967); Raphael Lemkin, Axis Rule in Occupied Europe (Washington, 1944), with his invention of "genocide" and "ethnocide," p. 49; and Eugen Kogon's Der SS Staat (Frankfurt, 1946); Henry L. Feingold, The Politics of Rescue: The Roosevelt Administration and the Holocaust (New Brunswick, 1970), especially pages 168-177; Louis W. Holborn (ed.), War and Peace Aims of the United Nations (Boston, 1944), I, 14, 99, 129, 482-484; II', 216-218, 266; Samuel Halperin, The Political World of American Zionism (Detroit, 1961), pp. 29-44; Philip Friedman and Koppel S. Pinson, "Some Books on the Jewish Catastrophe," Jewish Social Studies, XII (January, 1950), 88-89. 
form where Jewish historians tried to make a formal start for the study of the disaster. Under the auspices of the Conference on Jewish Relations, an organization founded in response to the rising tide of anti-Semitism in the 1930's, at the New York School for Social Research (an institution which especially helped to absorb refugee scholars from Germany), the "Problems of Research in the Study of the Jewish Catastrophe, 19391945 " came under scrutiny. ${ }^{7}$ Some of the scholars asked questions about the disaster in the context of Jewish history; some in the context of society.

Salo Baron and Philip Friedman spoke as rigorous historians of their people's past. We must make every effort to determine if the "lachrymose conception of Jewish history" is still valid; the primary task of the Jewish historian, proclaimed Baron, in the opening remarks to the Conference, was to identify and examine the "dissimilarities as well as the similarities between the great tragedy and the many lesser tragedies which preceded it." Friedman, one of a number of refugee scholars who had come from Central Europe to make their homes in the United States, made the destruction of European Jewry the focal point of his work. $\mathrm{He}$ bemoaned the quality of what he called "khurbn literature." To write, he said, "about the catastrophe or about personal experiences of this period has come to be a rather elemental passion, a popular movement which has its deep psychological and sociological roots. . .." The flood of "inferior" work from amateurs overshadowed "the worthwhile material" endangering the standing of serious work about "our catastrophe."

As a professional historian already at work on the Holocaust, Friedman distinguished between the general history of the war and the history of the Jewish people during the conflict. To the first, he assigned subjects of military campaigns, economic warfare, governments in exile, puppet governments in occupied countries, diplomacy, and resistance move-

${ }^{7}$ On the New York School for Social Research, see Alvin Johnson, Pioneer's Progress (New York, 1952). On the early history of the Conference, see Morris R. Cohen, A Dreamer's Journey (Glencoe, Ill., 1949), pp. 241-257.

8 Salo Baron, "Opening Remarks" to the Conference, Jewish Social Studies, XII (January, 1950), 14; Friedman, "Research and Literature on the Recent Jewish Tragedy," ibid., 25, 26. Twenty years later Lucy S. Dawidowicz, another Jewish historian who made the Holocaust an area of special interest, said much the same thing in a review of Nora Levin's The Holocaust: The Destruction of European Jewry, 1993-1945 (New York, 1968), in Jewish Social Studies, XXXII (July, 1970), 176-177. It is possible that the charge of amateurism is not always used in its proper sense: Jacob Robinson of YIVO does not consider Hannah Arendt a professional historian. Miss Arendt does not consider Robinson a professional historian: "The Formidable Dr. Robinson: A Reply," The New York Review of Books, V (January 20, 1966), 27. For examples of Miss Dawidowicz's work see "The Epic of the Warsaw Ghetto," Menorah Journal, XXXVIII (Winter, 1950), 88-103, and her long introduction to an anthology she called The Golden Tradition (New York, 1967). 
ments. "Of a secondary character only are the German terror and persecution of the civilian population, forced labor, population movements, the reactions of the civilian populations, the concentration camps... and similar factors." Research on the Jewish question had to be governed by the principal difference existing between Allied countries and European Jewry: the Allies fought for a democratic victory; European Jewry also fought, but for survival. Thus, for the Jewish historian "a different gamut of topics, subjects, and emphasis" presented themselves. "Most relevant are the suffering of the Jewish civilian population and until the final catastrophe of extermination, the struggle for life." Guarding himself against unimaginative and unrealistic compartmentalization he made the obvious plea: "just as the Jewish catastrophe in the Nazi era can be studied only in the broader context of the general events so the general European history of the period cannot be adequately interpreted without full understanding of the German war against the Jewish people."

Too much has happened and too much had been said for the Holocaust to remain in such seemingly modest parameters. The late Solomon Bloom, a student of European intellectual history, asked the sort of questions which in later years continued to arouse storms of controversy. ${ }^{10}$ After examining the careers of the Jewish police chief in Vilna and of Mordechai Rumkowski, a man he called the dictator of Lodz, Bloom insisted that "the moral position of the dictator must be recognized as a datum for study. In accepting it, the student has the example of older, but not inferior social scientists, like Thucydides . . . who did not shrink from judgments of religion, taste and morality. . . " For "Jewish social scientists, there is another obligation still." It is possible, Bloom thought, that the Jew who made life and death decisions for other Jews derived "his ideas from folklore rather than from the more selfconscious and sophisticated culture." Consequently, and, he might have added, in line with the ideas of Jewish secularists and anti-clerics, and even some devoutly religious Jews caught up in the destruction, the student of Judaism is obliged to raise the question about "the sense ... of mission; the hope or conviction that the Jews are an indestructible

9 Actually, these comments were made later, first in 1950 , at the International Conference on World War II in the West held in Amsterdam, and then 1951, in Jewish Social Studies, XIII (July, 1951), 235, 250. In 1950, he also published Oświecim in Yiddish (Buenos Aires); in 1954, he edited Martyrs and Fighters (New York).

$10 \mathrm{I}$ am assuming that the particular intensity of the controversy over Eichmann in Jerusalem (New York, 1964) is in part, but only in part, explained by the way readers responded to Bloom's kind of thinking. On the controversy, see Jacob Robinson, And the Crooked Shall be made Straight: The Eichmann Trial, The Jewish Catastrophe, and Hannah Arendt's Narrative (Philadelphia, 1965); Arendt, "Dr. Robinson," The New York Review of Books. The Leo Baeck Institute in New York has catalogued articles in the controversy under Miss Arendt's name. 
and eternal people, that "The Lord will leave a remnant." "For all of "these and other such turn up in the thinking and self-justification of the dictator. . . " Bloom dared the Jewish social scientists not to judge Jewish folklore, tradition, and ideology. ${ }^{11}$

Hannah Arendt pushed beyond him. For her, Hitler "was not like Jenghis Khan and not worse than some other great criminal but entirely different. The unprecedented is neither the murder itself nor the number of victims and not even 'the number of persons who united to perpetrate them." "It was much rather, she said in 1949, "the ideological nonsense which caused them, the mechanization of the execution and the central and calculated establishment of a world of the dying in which nothing any longer made sense." Concentration camps were "the laboratories in the experiment of total domination" in which the "human person" was "transformed into a completely conditioned being whose reactions can be calculated even when he is led to certain death. . ." Her evidence told her that "SS men in charge were completely normal; their selection was achieved according to all kinds of fantastic principles, none of which could possibly assure the selection of especially cruel or sadistic men." She could only "guess in what forms human life is being lived as though it took place on another planet," but it appeared "to be beyond doubt that within this whole system the prisoners did not fail to fulfill the same "duties' as the guards themselves"; it also appeared that those inmates who had "not done anything," in comparison with criminals and political prisoners, "were the first to disintegrate." Bruno Bettelheim, she knew, had argued in 1943, that the speed of disintegration resulted from "the middle-class origins of the 'innocents' - at his time mostly Jews." But he was wrong. "We know from other reports, especially also from the Soviet Union, that 'lower-class innocents' disintegrate just as quickly."12

Obviously, Miss Arendt was after something big and frightfully im-

I1 Solomon F. Bloom, "Toward the Ghetto Dictator," Jewish Social Studies, XII (January, 1950), 77, 78. See also his "Dictator of the Lodz Ghetto: The Strange History of Mordechai Rumkowski," Commentary, VII (February, 1949), 111-122. In addition to the remarks in Emanuel Ringelblum's Notes from the Warsaw Ghetto, ed. Jacob Sloan (New York, 1958), pp. 291, 336 337, see the following: Scroll of Agony: The Warsaw Diary of Chaim A. Kaplan, translated by Abraham I. Katsh (New York, 1965), pp. 323-340; Joseph Kermish, "First Stirrings," Yad Vashem Bulletin (October, 1963), pp. 12-19; (August, 1964), pp. 22-23. Elie Wiesel has told about rabbis in a concentration camp putting God on trial and finding Him guilty of charges officially leveled against Him. All of the charges had to do with the fate that had befallen Jews under the Nazis. Wiesel, "The Holocaust of European Jewry: One Generation Later," a lecture given at the National Hillel Summer Institute, Starlight, - New York, Summer, 1965.

${ }^{12}$ Hannah Arendt, "Social Science Techniques and the Study of Concentration Camps," Jewish Social Studies, XII (January, 1950), 64, 60, 61, 59, 63, 62; Bruno Bettelheim, "Behavior in Extreme Situations," The Journal of Abnormal and Social Psychology, XXXVIII (October, 1943), 417-452. 
portant. Her context was society; her searchlights philosophy, history, sociology, and psychology. When Baron tried to identify the "unprecedented aspects of the Nazi attack on Jews, quite apart from its magnitude," he identified these points of difference within Jewish history: the geographic area was much larger; there had occurred a much greater loss of the world's Jewish population; there had existed a "considered plan to eliminate all Jews"; there had been a "finality and immutability of the fate of Nazi victims"; all the other disasters in Jewish history "almost invariably [were] mass reactions unsupported by, indeed often directed against, state organs." When Miss Arendt tried to identify the unique and unprecedented in the camps, she insisted it was only to be found in the absence of utilitarian criteria, as these had usually been understood in the past. (She had in mind aggressive wars, massacres of enemy populations, massacres of a "hostile people," extermination of natives in the "process of colonization," slavery, driving forced labor gangs, or striving for world rule. $)^{13}$

These questions, generalizations, and judgments helped to determine the place of the Holocaust in American historical writing. In no time at all, Miss Arendt's words of 1944, seemed applicable to the kinds of thinking that engaged her, Bloom, and Bettelheim. In no time at all, too, historians in the United States seemed content to ignore the works of colleagues in America and elsewhere especially concerned with "the suffering of the Jewish population and ... its struggle for life," and with the efforts to find a place for the Holocaust in Jewish history. ${ }^{14}$

The publication and reception of Raul Hilberg's book in 1961 made that vantage point only too apparent for anyone who also knew the works of Gerald Reitlinger and Robert Koehl, and the English-language publications from the Wiener Library in London, Yad Vashem in Jerusalem, the Leo Baeck Institute, and YIVO Institute for Jewish Research in New York City. ${ }^{15}$ Hilberg's astounding study, preoccupied with

13 Baron, "Opening Remarks," p. 15; Arendt, "Social Science Techniques," p. 51.

14 Historians in the United States ignorant of the work of Jewish historians usually are also unaware that Jewish historians had problems similar to those of German scholars who were trying to find a place for the Hitler period in German history. For a summary of the problem of Jewish historiography, see Leni Yahil, "The Holocaust in Jewish Historiography," Yad Vashem Studies, VII (1968), 57-71. For comment on the problem in German historiography see Hans Herzfeld, "Germany: After the Catastrophe," in Walter Laqueur and George L. Mosse (eds.), The New History: Trends in Historical Research and Writing Since World War II (New York, 1967), pp. 77-89, and Hans Mommsen, "Historical Scholarship in Transition: The Situation in the Federal Republic of Germany," Daedalus, C (Spring, 1971), 475-508.

${ }_{15}$ Raul Hilberg, The Destruction of the European Jews (Chicago, 1961); Gerald Reitlinger, The Final Solution (London, 1953); Robert L. Koehl, RKFDV: German Resettlement and Population Policy, 1939-1945 (Cambridge, 1957); Wiener Library. Bulletin; Yad Vashem Bulletin; Yad Vashem Studies; Leo Baeck Institute Yearbook; 
the problems of bureaucracy and administration in modern totalitarian states, could only evoke admiration from anyone with respect for an approach which had been first used so successfully in the 1950's on Prussia by Hans Rosenberg, then a colleague of Bloom's at Brooklyn College. ${ }^{16}$ Even though Hilberg stated explicitly that his book was about Germans and the ways in which they hunted and killed Jews, his loose comments about Jewish behavior made his work generally known and talked about. ${ }^{17}$ It was clear enough that his study was based largely on German sources, but an American scholar thought his section explaining Jewish passiveness was one of the finest in the book. By itself such praise would not be so startling, even in The Journal of Modern History, but the same reviewer thought that Hilberg had gone "too far in his wholesale condemnation of the German bureaucracy. There were courageous officials who did what they could to alleviate the lot of the Jews. . ."18 He saw no reason to criticize Hilberg for his "wholesale" judgments about Jews during hundreds of years of European history. ${ }^{19}$

\section{III}

I believe now that the indifference to the Jewish side of the war may have been aggravated by a strange transformation in the vocabulary people used when they spoke and wrote about the catastrophe. I have used "Holocaust" in this article, but in 1949, there was no "Holocaust" in the English language in the sense that word is used today. Scholars and writers had used "permanent pogrom"-this term of Jacob Lestschinsky in 1941, meant that the pogrom had "no passing or limited political and economic aims but the extirpation, the physical elimination of its Jewish citizens" - or the "recent catastrophe," or the "recent Jewish catastrophe," or the "great catastrophe," or "disaster," or "the disaster." Sometimes writers spoke about annihilation and destruction without use of any of these terms. All of them, by intent or accident, translated accurately the Hebrew words shoa and khurban because like them they carried only secular freight. (Yiddish, the other language so

YIVO Annual, VIII (1954) and XXI (1969). The Leo Baeck Institute has offices in New York, London, and Jerusalem.

${ }_{16}$ Hans Rosenberg, Bureaucracy, Aristocracy, and Autocracy: The Prussian Experience, 1660-1815 (Cambridge, 1958). The connection is direct and personal. See Hilberg's expression of gratitude to Rosenberg in Destruction, preface.

${ }_{17}$ For examples of these kinds of comments see Hilberg, Destruction, pp. 662-669, 675,676 .

18 Andreas Dorpalen, in The Journal of Modern History, XXXIV (June, 1962), 226-227. See also Gerhard L. Weinberg, in The American Historical Review, LXVII (April, 1962), 694-695.

${ }_{19}$ If one takes him literally, Hilberg ranges over 2,000 years, covering the entire Diaspora. See his comment in Destruction on p. 666. 
profoundly involved with the disaster and with the literature about it, contributed besides khurbn, the word umkummen. $)^{20}$

In 1953, the state of Israel formally injected itself into the study of the destruction of European Jewry, and so became involved in the transformation. In the anguish of mourning the dead of Europe and the dead who fell in Israel's lonely fight for nationhood, the Knesset gave posthumous citizenship to the 6,000,000 and established, in controversy, Yad Vashem as a "Martyrs' and Heroes' Remembrance Authority" in language not especially encouraging to the spirit of objective scholarship. "May every person in Israel, every Jew wherever he may be, know that our People has its own reckoning, the reckoning of the generations of the Eternal People-a reckoning of an Eternal People, whose entire history is proof and evidence of the prophetic promise: And I said unto you in your blood, 'Live' [Ezekiel, 16-6]." Two years later Yad Vashem translated shoa into "Disaster" and announced for itself and YIVO in New York that henceforth the study of the catastrophe would be divided this way: "The approach of the Disaster, 1920-1933"; "The beginnings of the Disaster, 1933-1939"; and "The Disaster, 1939-1945."21

But then the change occurred quickly. When catastrophe had lived side by side with disaster the word holocaust had appeared now and then. In 1951, for example, Jacob Shatzky of YIVO spoke of "the Nazi holocaust," but apparently he did not mean to apply the phrase specifically to the destruction of European Jewry. Between 1957 and 1959, however, "Holocaust" took on such a specific meaning. It was used at the Second World Congress of Jewish Studies held in Jerusalem, and when Yad Vashem published its third yearbook, one of the articles dealt

${ }^{20}$ Jacob Lestschinsky, Erev Churbn (On the Eve of Destruction) (Buenos Aires, 1951); Samuel Gringanz, in Jewish Social Studies, XIV (October, 1952), 326-327; Leo Schwartz, ibid., 378-379; Theodor Abel, ibid., V (January, 1943), 79; Werner J. Cahnman, "A Regional Approach to German Jewish History," ibid., (July, 1943), 211-224; Oscar Karbach, "The Founder of Political Antisemitism," ibid., VII (January, 1945), 3-4; Adolf Kober, "Jewish Communities in Germany from the Age of Enlightenment to Their Destruction by the Nazis," ibid., IX (July, 1947), 230-238; Lestschinsky, "The Anti-Jewish Program: Tsarist Russia, The Third Reich and Independent Poland," ibid., III (April, 1941), 147-148; Yad Vashem, Aims and Activities (Jerusalem, 1955); Friedman, "Research and Literature," used most of these terms interchangeably. For examples of the use of shoa in Biblical writings see Ps. 35-8, 63-10, 35-17; Job, 30-3, 14, 38-27; Ez. 38-9.

${ }_{21}$ 'Yad Vashem, Martyrs' and Heroes' Remembrance Authority (Jerusalem, 1955), pp. 7, 9, 17, 19; Jerusalem Post, August 20, 1953. The Zionist Congress discussed such an authority in August, 1945. The Va'ad Leumi of Palestine Jewry kept the idea alive. After the establishment of Israel, Ben Zion Dinur, historian and Minister for Education and Culture, was instrumental in the Knesset's passage of the bill establishing Yad Vashem; Professor Dinur became its first head. Controversy in the Knesset involved the opposition of Herut to Moshe Sharet's government over the Reparations Agreement with Germany, and the Knesset's left-wing members, some of whom wanted to mention by name in the law specific groups of fighters. 
with "Problems Relating to a Questionnaire on the Holocaust." Afterwards Yad Vashem switched from "Disaster" to "Holocaust" although it retained the title of its yearbooks Yad Vashem Studies of the Jewish Catastrophe and Resistance. ${ }^{22}$

In other words, conversion of the destruction of European Jewry into "Holocaust" began before the publication of Hilberg's book and before Eichmann's capture. There were those who refused to use the word so exclusively, preferring to apply it to the Civil War, World War II or III (a nuclear holocaust), but there appeared no formal effective opposition. Within the Jewish world the word became commonplace, in part because Elie Wiesel and other gifted writers and speakers, in public meetings or in articles for Commentary and journals such as Judaism and Midstream made it coin of the realm. By 1968, even the Library of Congress had no choice. As Jewish scholars in various parts of the world and in various languages revealed with Jewish sources the details of the suffering of the Jewish population and its struggle for spiritual and physical survival, the international serial and monographic literature using "Holocaust" became so significant, said the Library's Catalogue Division, committed to a policy of following usage, that it felt compelled to create a major entry card: "Holocaust-Jewish, 1939-1945." ${ }_{23}$

${ }_{22}$ Jewish Social Studies, XIII (April, 1951), 175-176. Bernard Mark, "Problems Related to the Study of the Jewish Resistance Movement in the Second World War," Yad Vashem Studies, III (1959) 41-65; Zvi Bar-Or and Dov Levin, "Problems Relating to a Questionnaire on the Holocaust," ibid., 91-117. These papers and a number of others, such as Friedman's "Problems of Research on the European Jewish Catastrophe," pp. 25-40, published in this volume were read at the Second World Congress of Jewish Studies held in Jerusalem in 1957. The Yad Vashem Bulletin (April, 1957), p. 35, has a reference to "Research on the Holocaust Period." Of course, there had been writers who spoke of the Nazi holocaust even before 1951, but their use of the phrase was applied to the general destructive impact of Nazism. Morris Cohen used the phrase in that way as early as 1945. Cohen, A Dreamer's Journey, pp. 256-257.

${ }_{23}$ Higham, History, pp. 200, 204; Robert E. Osgood, Ideals and Self-Interest in America's Foreign Relations (Chicago, 1964), p. 415; Louis L. Snyder, The War: A Concise History 1939-1945 (New York, 1960), preface, and the caption underneath a picture of Hiroshima after the bomb-this picture is opposite a page showing "Ghastly scenes in a Nazi extermination camp." Holocaust! by Paul Benzaquin (New York, 1959) was a novel about the Coconut Grove fire, but increasingly the word was used in titles of anthologies, memoirs, and surveys of the destruction of European Jewry: Alexander Donat, The Holocaust Kingdom: A Memoir (New York, 1965); Sam E. Bloch (ed.), Holocaust and Rebirth (New York, 1965); Jack Kuper, Child of the Holocaust (London, 1967); Levin, Holocaust; Albert H. Friedlander, Out of the Whirlwind: A Reader of Holocaust Literature (New York, 1968); Jacob Glatstein, Anthology of Holocaust Literature (New York, 1969); Irving Halperin, Messengers from the Dead: Literature of the Holocaust (Philadelphia, 1970). My information about the Library of Congress comes from Charles Bead and Theodore Wiener via telephone on August 10, 1971. The Catalog Division has some correspondence from individuals who tried to find out why the new category was being used. Before 1968 , the Library catalogued "Holocaust" books under various subcategories of World War II-Personal Narrative, Jewish, is one example - or under the history of Jews by communities. 
Thus it was that a word brought into the English language by Christian writers centuries ago-they took the Greek word used in the Septuagint exclusively for translating words in the Torah meaning sacrifices consumed by fire-came to be the noun symbolizing a new phenomenon in Western civilization: the destruction of European Jewry. It was also, I believe, that a change in word usage in the English language helped to shift concern from the particularity of the disaster within Jewish history to an emphasis on its uniqueness in modern history. In turn, that shift made it easier to level the charge of parochialism against Holocaust advocates, who, like myself, usually cannot conceive of Auschwitz without the Nazis' anti-Semitism. After all, Miss Arendt had all along insisted that the uniqueness of Auschwitz lay elsewhere! "Antisemitism by itself," she declared, "has such a long and bloody history that the very fact that these death factories were chiefly fed with Jewish 'material' has somewhat obliterated the uniqueness of this operation. . . Antisemitism only prepared the ground to make it easier to start the extermination with the Jewish people."

However, that difference between Holocaust advocates and those who share Miss Arendt's views on the place of anti-Semitism in the development of Nazi Germany's particular methods of domination and annihilation must not obscure the more fundamental agreement between them. In its totality, she also said in 1949, the German way "must cause social scientists and historical scholars to reconsider their hitherto unquestioned fundamental preconceptions regarding the course of the world and hu-
man behavior." ${ }_{24}$

\section{IV}

For most historians in America World War II cast so narrow a shadow that they almost missed the destruction of European Jewry. After 1945, they wrote textbooks about modern Europe, the twentieth century, or about the history of the United States without any concern for the kind of appreciation a Friedman or a Miss Arendt had for the actual past, or as it had been told by some colleagues here, in Europe, and Israel. ${ }^{25}$ Moreover, the Holocaust did not usually reverberate in the consciousness of historians in the United States when they wrote the secondary litera-

${ }^{24}$ Roland de Vaux, O. P., Ancient Israel Its Life and Institutions (New York, 1961), p. 415; Arendt, "Social Science Techniques," pp. 49, 53; in the original these passages appear in a different sequence. Of course, from the very beginning, many people said does not record a crime ever perpetrated a $H$. Jackson declared in 1945: "History : . . out with such calculated cruelty...." See Wainst so many victims or one ever carried

Holborn, War and Peace Aims, II, 216-218, 266.

Yad Vashem Studies, VIII (1970), 183-202. 
ture of their profession. Admittedly, that literature is vast, but it would appear that the generalization applies to most colleagues writing about recent German and American history, or about World War II in particular. Leaving aside the historians whose primary professional preoccupation is Jewish history, after one adds to scholars already mentioned George Mosse, Fritz Stern, and Gunther Lewy, one soon runs out of names of historians working in the United States who have moved the Holocaust toward the center of their historical consciousness. ${ }^{26}$

No doubt there is many a historian whose work does not touch either subject, but who, in strange places, reveals the presence of each in his historical imagination. Richard B. Morris, for example, known especially for his work on colonial America and the early national period, felt compelled to write in a review that $A$ Dual Heritage "is a serious contribution not only to an understanding of the role of American Jewry in the generation before the Holocaust but also to the development of the movement for political reform in America." Peter Gay, whose pagan hero in the enlightenment was David Hume, in his first venture into American history, wrote a beautiful dedication to "the many thousands of pilgrims, Jewish and not Jewish . . whom Hitler compelled to discover America ... to the D.P.'s who came out of the camps without families and who, with the indelible numbers on their arms and their indelible memories . . . started new families. . . " All of these, he said, "were in their own ways heroes ... in danger of being forgotten and deserve to be remembered." 27

${ }^{26} \mathrm{I}$ base this generalization primarily on an examination of a number of professional journals, especially the reviews of books on subjects related to the Holocaust. The journals I looked at most carefully were The American Historical Review, The Journal of American History, and The Journal of Modern History. See also the periodical guide, America: History and Life, I-VII. There are also historians like Arthur Hertzberg, Rudolf Glanz, and Zosa Szajkowski, who have made important contributions to the complex history of the background of the Holocaust, but, in comparison to those listed, their primary preoccupation was Jewish history. Hertzberg, The French Enlightenment and the Jews (New York, 1968), pp. 5-6, says his book is an effort to explain Auschwitz: "The era of Western history that began with the French Revolution ended in Auschwitz." Szajkowski has published important articles, some in American Jewish Historical Quarterly: "A Note on the American-Jewish Struggles Against Nazism and Communism in the 1930's," LIX (March, 1970), 277-281 is an example for American history; for French history, see Jews and the French Revolutions (New York, 1970). For Glanz, see Studies in Judaica Americana (New York, 1970), and "The Jewish Execution in Medieval Germany," Jewish Social Studies, V (January, 1943), 3-26. George Mosse has written The Crisis of German Ideology (New York, 1964), and Germans and Jews (New York, 1970); Fritz Stern, The Politics of Cultural Despair (Berkeley, 1961); Gunther Lewy, The Catholic Church and Nazi Germany (New York, 1964). See also Robert F. Byrnes, Antisemitism in Modern France (New Brunswick, 1950), and Michael A. Meyer, The Origins of the Modern Jew (Detroit, 1967).

27 Richard B. Morris' review of Naomi W. Cohen's A Dual Heritage: The Public Career of Oscar S. Strauss (Philadelphia, 1969), in Jewish Social Studies, XXXII (July, 1970), 227; Peter Gay, A Loss of Mastery (Berkeley, 1966), p. vi. 
In general, however, I believe, the place of the Holocaust in the secondary literature is like its place in histories of World War II written by Louis Snyder and Gordon Wright. Snyder's was a popularized account based on his vast knowledge of modern European history. From his own preface, where he speaks of the "devastating man-made holocaust of World War II," and from Eric Sevareid's remarks in the introduction ("in World War II ... we shivered in the cold stench of medieval mania loosed from the catacombs of the Dark Ages, for this time men saw in the Germanic insanity mass butchering following from deliberate purpose, ...") there is no doubt Snyder understood what happened, but in the work itself he makes about as much room for the Holocaust as a good survey of Western civilization since Columbus. ${ }^{28}$

Wright's account is different. ${ }^{29}$ Even though in much of this book the destruction of European Jewry is at the periphery of his consciousness, he does stop for a moment and devotes two, long, tightly written paragraphs to the Nazi racial policy which "reached its epitome . . . when applied to the Jews." He does not attend to the special set of circumstances in which Jews found themselves and seems overly concerned to make sure his reader understands that Jews "were not the only victims of the extermination camps." But, by leaning heavily on Hans Buchheim and his German colleagues, and on Koehl's monograph he is able to convey an impression about the execution of the Final Solution with which scholars steeped in Jewish sources could find little fault. ${ }^{30}$ The problem with Wright lies elsewhere.

For Wright there is no Jewish community, and perhaps for that reason no Jewish resistance. In and of itself his silence on the subject of resistance among Jews would not be so startling. However, Wright has an especially good discussion of the entire resistance movement in Europe in which he seeks to explain why patterns of resistance were different in character and timing from one country to the next. Thus, he lauds the

28 Snyder, World War II. Some historians may have a methodological principle which prevents them from asking "why" if their evidence is silent about Jews, or reveals decisive indifference to them. I do not pretend to understand such a principle, but see Osgood, Ideals, pp. 400, 415, and William E. Leuchtenburg, Franklin D. Roosevelt and the New Deal 1932-1940 (New York, 1963), p. 286. On World War II literature, see also Louis Morton, "World War II: A Survey of Recent Writings," The American Historical Review, LXXV (December, 1970), 1987-2008.

${ }_{29}$ The quotations come from The Ordeal of Total War 1989-1945 (New York, 1968), pp. 35, 74, 75, 93-94, 101, 112, 126-127, 156, 158-159, 162.

30 Koehl, $R K F D V$, pp. 198,199 . See also his sensitive remarks in a review of Eberhard Kolb's Bergen Belsen: Geschichte des "Aufenthaltslagers" 1949-1945 (Hanover, 1962), in The Journal of Modern History, XXXV (September, 1963), 327328. A comparison of Gordon Craig's The Politics of the Prussian Army 1640-1945 (New York, 1964) with Karl Demeter's The German Officer Corps in Society and State 1650-1945 (London, 1965) is also instructive. 
Poles: "Hitler's policy, to be sure, left Poles virtually no choice: not to resist meant ruthless exploitation and national degradation. To a people as proud and stiffnecked as the Poles their duty was clear: they gradually organized an elaborate network of institutions that some Poles described as a 'secret state'." Their uprising in 1944, in Warsaw, was one of the "most heroic chapters in the history of the European resistance." In the text there is not a whisper about that other uprising in Warsaw a year before when a tiny group of descendants from the Bible's stiff-necked people rose against the Germans. ${ }^{31}$

By comparison, and only by comparison, Wright spends an inordinate amount of space probing the particularity of the admittedly complex and poignant positions in which anti-Nazi Germans found themselves. He wrote:

More than 200,000 Germans were imprisoned or interned during the prewar years, and many others went into voluntary exile. The flow into the concentration camps continued after 1939, though at a slower rate. This preventive action destroyed much of the potential resistance leadership. Furthermore, the Nazi regime's police state techniques made underground plotting exceptionally hazardous, for no one could be sure whom to trust. An additional handicap was Allied suspicion. Efforts by resistance leaders to make contact with Allied officials were usually viewed skeptically by the latter; the German underground failed to get the kind of aid and encouragement that buoyed up the spirits of resisters elsewhere. All in all, it is perhaps astonishing that active resistance ever developed in war-time Germany.

Word for word, Hannah Arendt and Oscar Handlin have used almost identical language about Jewish resistance. ${ }^{32}$

A recent issue of The American Historical Review illustrates the ways the Holocaust reverberates in the minds of European historians working in the United States on subjects other than the war. Fritz Stern, Gerald D. Feldman, and Henry Ashby Turner each examined the subject of economics and politics in the period between Bismarck's time and the rise of Hitler. To be sure, writing about the friendship between Gerson Bleichröder and Bismarck all but forced Stern to say something about the Jewish component of the relationship, but Stern demonstrates that he has worked through the conceptual problem of the place of GentileJewish relations in nineteenth-century German history, and knows what

${ }^{31}$ This comment does not apply to the bibliography where there are references to the uprising in 1943, but under the section "Nazi Persecution of 'Racial' and Political Enemies." There are no entries under "Resistance Movements."

${ }^{32}$ Arendt, "Formidable Dr. Robinson"; Oscar Handlin, "Jewish Resistance to the Nazis," Commentary, XXXIV (November, 1962), 398-405. 
is demanded of him as a European historian by virtue of the destruction of European Jewry. "What was it that linked the Jew-hedged in by apprehensions and uncertainties, a partial stranger in the land he loved too well, and the Junker. . . ." He remarks that Bleichröder's visit to Versailles in 1871 "inflamed the already surprisingly fierce anti-Semitism in those all-Gentile surroundings." Finally, he takes the long view:

Bleichröder's spectacular rise marked an important stage in the history of German Jewry. ... In their rise and fall the Bleichröders describe a kind of Jewish Buddenbrooks. The social and psychological precariousness of their position, always present beneath the glittering surface, became desperately clear after the rise of the Nazis. Bleichröder's descendants appealed to Adolph Eichmann to be exempted from deportation. It was a poignant, futile end to the story of the Bleichröders in Germany.

There is nothing like this at all in the articles by Feldman and Turner, who are interested in the relationship of big business to the Weimar Republic and the Nazi Party. Turner includes the following passage, which is the only reference in both pieces to Jews and anti-Semitism in Germany: "[Emil] Kirdorf did not withdraw because the Nazis were antidemocratic, aggressively chauvinistic, or anti-Semitic (even though he, like most business leaders, was himself not an anti-Semite). What drove him out of the party was the social and economic radicalism of the Leftwing Nazis." Fortunately, for readers of The American Historical Review, Ernst Nolte, a German scholar from Marburg, admittedly associated by some with a monolithic and "totalitarian" interpretation of National Socialism, identified an important issue which simply was excluded by Feldman and Turner. Hitler seemed to share the "passionate thinking" of most businessmen, together with officers, professors, clergymen, civil servants, and even functionaries of the Social Democratic Party, and therefore gained their support. "The guilt of the German industrialists lies not in the fact that they were children of their time. . . It lies in their failure to recognize that the fundamental nature and ultimate consequences of National Socialism-the self-sufficient racial state, withdrawing from all disturbing communication with the world. . .", 33

I have left to the last historians working in the field of American history because the phenomenon of the Holocaust at the moment directly

${ }^{33}$ Fritz Stern, "Gold and Iron: The Collaboration and Friendship of Gerson Bleichröder and Otto von Bismarck"; Gerald D. Feldman, "The Social and Economic Policies of German Big Business, 1918-1929" ; Henry Ashby Turner, Jr., "Big Business and the Rise of Hitler"; Ernst Nolte, "Big Business and German Politics: A Comment"; all of which are to be found in The American Historical Review, LXXV (October, 1969), 38, 40, 46, 78; Mommsen, "Transition," p. 489. 
affects only the years since 1933. Until 1962, only Handlin ventured into print specifically examining aspects of the Holocaust in Europe, but in the last few years a number of book-length studies have looked at the Jewish refugee crisis of the 1930's and American policies towards Jews seeking to leave Europe then and during the war itself. All these works address themselves to the question Leon Poliakov raised in 1949, two years after Henry Morgenthau, Jr. had published his dramatic article in Collier's. Are Morgenthau's charges well-founded, he asked? "Is it true that another attitude in 1942, 1943, and 1944 would have made it possible to save the lives of hundreds of thousands of Jews?" He knew only the historians of the future could provide the answer. ${ }^{34}$

In 1971, in that future, after a number of articles and after three books on the subject-Henry Feingold uses the word "Holocaust" in his subtitle-the question remains as open-ended as it was in the midst of World War II. In conjunction with other studies about Roosevelt and his administrations, these works are helping us to know what decisions were in fact made about European Jewry by men in government and all other elements of the American population. ${ }^{35}$ As that knowledge is be-

34 Handlin, "Resistance"; Leon Poliakov, "Mussolini and the Extermination of the Jews," Jewish Social Studies, XI (January, 1949), 1; Arthur D. Morse, While Six Million Died: A Chronicle of American A pathy (New York, 1968); David S. Wyman, Paper Walls: America and the Refugee Crisis (Amherst, 1968); Feingold, Politics of Rescue; Edward N. Saveth, "Franklin D. Roosevelt and the Jewish Crisis 1933-1945," American Jewish Yearbook, XLVII (1945-1946), 37-50; David Brody, "American Jewry, The Refugees and Immigration Restriction (1932-1942)," Publications of the American Jewish Historical Society, XLV (June, 1956), 219-247; Sheldon Spears, "The United States and the Persecution of the Jews in Germany, 1933-1945," Jewish Social Studies, XXX (October, 1968), 215-242. I am aware that American historians can use the Holocaust as one of the ways for showing FDR's clay feet and for making the argument that American society became increasingly dehumanized after World War I. James R. Leutzer, for example, knows that Roosevelt could have "done something, had he tried," that "Long was a sticking cog in the machinery," and "that human lives were the subject of the paperwork routinely shuffled from inbox to pigeon hole." See The Journal of American History, LVIII (June, 1971), 216-217. James T. Patterson adds Roosevelt's "reluctance to admit Jewish refugees" to the president's "timid support" of the Fair Employment Practices Commission during the war and to his "dealing with Japanese Americans." Patterson's sum of such evidence enables him to say that James MacGregor Burns in his Roosevelt: The Soldier of Freedom (New York, 1970) shows FDR to have been a "better Jeffersonian in principle than in practice." Ibid., p. 218. Robert A. Divine, on the other hand, makes no reference at all to the Jewish refugee crisis in a review of Burns' second volume of his study of Roosevelt in Political Science Quarterly, LXXXVI (June, 1971), 289. See also Robert H. Ferrel's review of Divine's Roosevelt and World War II (Baltimore, 1969) in The American Historical Review, LXXV (December, 1969), 613-614.

${ }_{35}$ In addition to the books already cited see also Arnold A. Offner, American Appeasement: United States Foreign Policy and Germany, 1939-1938 (Cambridge, 1969); Selig Adler, The Isolationist Impulse: Its Twentieth Century Reaction (Glencoe, Ill., 1966); Robert A. Divine, American Immigration Policy, 1924-1952 (New Haven, 1957); John M. Blum (ed.), From the Morgenthau Diaries (3 vols.; Boston, 1959-1967); Allan Nevins, Herbert Lehman and His Era (New York, 1963); Robert Dallek, Democrat and Diplomat: The Life of William E. Dodd (New York, 1968). 
coming grounded in reliable evidence, the written history of the United States since World War I is being drawn into the entire question of the destruction of European Jewry. In time, no doubt, some scholars examining American history since 1914 will also wonder if America's responses to the Armenian disaster in the first year of the war were symptomatic of fundamental changes in American society which led to the institutionalization of racism and nationalism in the quota principle of immigration legislation. ${ }^{36}$

One other area in American history has involved the Holocaust. Stanley Elkins has used Bruno Bettelheim and other students of personality disintegration in the concentration camp to probe the effects of slavery on personality. Coming at a time when many historians were especially attracted to the behavioral sciences, his concern with personality changes prompted much informal and formal discussion about Jewish behavior in concentration camps and the use of each without the other in the study of adult personality changes under slavery or in modern industrial society. ${ }^{37}$

These discussions have probably expanded the reverberative distance of the Holocaust in the time consciousness of American historians, but they seem not to have made them more aware of the substantial histori-

36 John Higham in his Strangers in the Land (New Brunswick, 1955) makes some suggestions along this line at the very end of the book. Charles A. Beard, The Open Door at Home (New York, 1934), pp. 179-209. In 1935, the quota concept was being applied by the Works Project Administration in Chicago for assuring blacks at least five percent of the jobs in the construction industry. Correspondence in the files of Lawrence Oxley: National Archives. I am grateful to Professor James Gross, New York State School of Industrial and Labor Relations, Cornell, for this reference.

${ }^{37}$ Stanley M. Elkins, Slavery: A Problem in American Institutional and Intellectual Life (Chicago, 1963). As well as Bettelheim, Elkins refers to Eli Cohen's Human Behavior in the Concentration Camp, translated by M. H. Braaksman (New York, 1953). Although he does not refer to him, it is important to know that Erik $H$. Erikson, always conscious of the historical context in which a person develops, had written on a related phenomenon in "Hitler's Imagery and German Youth," Psychiatry, V (November, 1942), 475-493. This essay was reprinted in Clyde Kluckhohn and Henry A. Murray (eds.), Personality in Nature, Society, and Culture (New York, 1948), pp. 485-510; he also published "Wholeness and Totality," in Carl J. Friedrich (ed.), Totalitarianism (Cambridge, 1954). The latest use of psychiatry is made by Peter Lowenberg in "The Unsuccessful Adolescence of Heinrich Himmler," The American Historical Review, LXXVI (June, 1971), 612-641. For historians' discussion of slavery and concentration camps see "The Question of 'Sambo," Newberry Library Bulletin, V (December, 1958), 14-40; Earle E. Thorpe, "Chattel Slavery and Concentration Camps," Negro History Bulletin, XXV (May, 1962), 173-175; Eugene Genovese, "Rebelliousness and Docility in the Negro Slave: A Critique of the Elkins Thesis," Civil War History, XIII (December, 1967), 308-309, 312-313; George M. Frederickson and Christopher Lasch, "Resistance to Slavery," ibid., 315-329; Kenneth Stampp, "Rebels and Sambos: The Search for the Negro's Personality in Slavery," The Journal of Southern History, XXXVII (August, 1971), 376-392. To me it is extraordinary that such knowledgeable students of slavery as Genovese, Stampp, and Thorpe can remain satisfied with evidence from Bettelheim (1943), Kogon (1946), and Miss Arendt (1953). 
cal literature available from their colleagues especially involved with the Jewish side of the Holocaust. Why not? (1) Amateurs continue to flood the market, overshadowing the good work available in English, and perhaps leaving unsoiled only Hilberg and Miss Arendt, just because their work is not steeped in Jewish sources and has been severely attacked by the other side. ${ }^{38}$ (2) Historians in the United States, sensitive to our closeness to the events, may consider the combined efforts of Reitlinger and Hilberg and of Miss Arendt as the best obtainable for the time being. (3) From the very beginning, perhaps, historians here assumed the subject was the special domain of colleagues in Europe, particularly in Germany. (4) Efforts among social scientists to identify the fundamental components of human behavior make the particularity of detailed European history about Jews, Jews and Gentiles, and about Jewish behavior under German rule all but unnecessary for even the historian engaged in analogical analysis. (5) The other millions who died in World War II, and since then, the outrageous suffering and killing of millions in Africa and Asia make it difficult to treat the destruction of European Jewry as another unique experience of the peculiar Jewish people. (6) Finally, it is also possible that historians in the United States may well consider the Holocaust as a subject whose primary significance lies in Jewish history and as such is parochial in nature.

There are three cogent reasons for suspecting that this last answer is closest to the mark of an admittedly fascinating but difficult problem whose roots are deep and entangled. (1) As a breed, historians are not especially heroic. They know that their work will be scrutinized for the tell-tale marks of anti-Semitism or self-hate. (2) The Jew has not been an indigenous element in the literary imagination of Americans as he has been in the imagination of Europeans. Leslie Fiedler once claimed that when the Jew did appear in American letters, as in the 1920's, he was usually an importation from medieval Europe's storehouse of stereotypes. ${ }^{39}$ (3) Most working historians are so overwhelmed by nationalism that they forget in practice what they know in theory. David Potter ten years ago reminded his colleagues that they do not treat nationalism as one of many sets of competing devotions within one person or group of persons residing in a political territory. Thus, they often assume as legitimate only one set without considering the legitimacy of

${ }^{38}$ Dawidowicz, Jewish Social Studies, XXXII (July, 1970). Miss Arendt provides evidence of the animosities between herself, Hilberg, and other Jewish commentators in "Formidable Dr. Robinson."

${ }^{39}$ Leslie A. Fiedler, "Negro and Jew-Encounter in America," Midstream, II (Summer, 1956), 6-8. 
any of the competitors. ${ }^{40}$ The Jew in any nation-state in the hands of that kind of historian is always at a competitive disadvantage. Hence, to Samuel Eliot Morrison and Henry Steele Commager, Anne Frank was a little "German" girl even when writing her diary. ${ }^{41}$ In 1969, however, Anne became a "Jewish" girl.42

Evidence abounds that Americans are becoming more sensitive about the complexity of their nationality. "Southern novelists, Jewish writers, Negro authors, and Beat pundits," we are told by the Literary History of the United States evaluating postwar fiction in America, "had emerged from the tragic underground of culture as the true spokesmen of midcentury America." ${ }_{43}$ No doubt in response to them and in response to the events of their times, historians in the United States struggled to make room for Blacks and Indians as they never had before, and for the first time appeared to find new room for Jews and other ethnic groups whose devotions American historians, beclouded by nationalism or material environmentalism, sometimes attributed to the slow rate of Americanization or disparagingly considered as distractive delusions of romantic nationalism. ${ }^{44}$

But for the present, it is fair enough to say that there is no Holocaust phenomenon in the historical writing of Clio's disciples in the United States, except among practitioners of Jewish history and Jewish intellectuals.

${ }^{40}$ David A. Potter, "The Historian's Use of Nationalism and Vice Versa," The American Historical Review, LXVII (July, 1962), 924-950.

${ }^{41}$ The Growth of the American Republic (2 vols.; New York, 1962), II, 605-606.

${ }^{2}$ Ibid., (6th rev. ed., 1969), pp. 609-610. See also p. 536 of the same work.

${ }^{43}$ Robert E. Spiller, et al., Literary History of the United States (2 vols.; New York, 1963), I, 1420. There are some other indications of this trend. In 1971, for the first time in its history, the American Historical Association at its annual convention devoted one session to the "Holocaust" (co-sponsored by the YIVO Institute for Jewish Research and the Conference Group for Social and Administrative History), and another to "The Prussian Government and the Jews in the Wilhelmian Era." American Historical Association, Program of the Eighty-Sixth Annual Meeting, December 28, 29, 30 (Washington, D.C., 1971), pp. 53, 59. The following titles were also published during that year: Michael R. Marrus, The Politics of Assimilation: A Study of the French Jewish Community at the Time of the Dreyfus Affair (New York, 1971), and Donald L. Niewyk, Socialist, Anti-Semite, and Jew: German Social Democracy and the Problem of Anti-Semitism, 1919-1933 (Baton Rouge, 1971).

44 In addition to the work of Charles A. Beard, see, for example, Sam B. Warner, Streetcar Suburbs (Cambridge, 1962), pp. 11-12; Caroline F. Ware (ed.), The Cultural A pproach to History (New York, 1940), pp. 1, 72; Christopher Lasch, "The Trouble with Black Power," The New York Review of Books, X (February 29, 1968), 4-14. 